\title{
Empirical Analysis of Cassava Farmers Socio - Economic Characteristics and Their Access to Agricultural Information in Delta State, Nigeria
}

\author{
Omoregbee*, F. E.; U. S. Awhareno And I. D. Ekpebu \\ Department of Agricultural Economics \& Extension Services, Faculty of Agriculture, University of Benin, \\ Benin-City
}

\begin{abstract}
The study focused on the accessibility of cassava farmers to agricultural information in Delta State. Multi-stage sampling technique was used to select 146 cassava farmers. Data collected through structured questionnaire were analysed using frequency counts, percentages and logit regression analysis. Findings revealed that the Ministry of Agriculture, friends and neighours, radio and television were major sources of information to respondents. Majority had access to information on available market for produce $(45.2 \%)$, produce price (48.8\%), input price (37.0\%), improved cassava varieties (50.7\%), fertilizer type $(43.2 \%)$ and fertilizer application (46.6\%). Inferential statistics revealed that education $(t=2.522)$, association membership $(t=2.275)$ and extension contact $(t=2.080)$ had a significant influence on respondents access to agricultural information. It is recommended that $A D P$ should be adequately funded to bridge the gap between researchers and farmers while adult education and membership of association should be encouraged among peasant farmers in Delta State.
\end{abstract}

Key words: Cassava; Farmers; Socio-economic; Access; Agricultural information; Delta State.

\section{Introduction}

Information is an important factor in any human endeavour as it enables individuals make timely and informed decisions that would assist them in what ever activity they might be engaged in. Agricultural information dissemination is crucial to the productivity of farmers and makes them learn about those things which they are not aware of (Banmeke and Olowu, 2005). Ozowa (2004) noted that information and communication are essential ingredients needed for effective transfer of technology that are designed to boost agricultural production. For any information to be useful, it must be well communicated to the end users. The nature and form in which agricultural information are package will require some specialized skills by farmers to access. If agricultural information are package in visual form and readily made available to farmers, it will greatly influence the adoption of such farming technique irrespective of age, sex and educational level. Torimiro (1997) observed that the attainment of higher level of education and professional qualification is a very good springboard for the assessment of agricultural information intake or access by farmers. It will be very difficult for a farmer who cannot read to access agricultural information package in print media.

However, different categories of household and individual have different information needs, and their current and potential access to information sources may also be different. Different people have different levels of access to the individuals and institutions which mediate these flows of information. If we can identify those to which people have most access or regard as the most reliable, external agencies can use them as channels for getting new agricultural information into the communities or to specific categories of people and obtaining feedback information needs.

For farmers to move from their crude production system to a better and more commercialised farming, they need adequate agricultural information on modern agricultural farming techniques. ICS-Nigeria (2007) noted that the sustainability of cassava production is threatened by a vicious cycle of declining soil fertility and increasing problems of pests, diseases and weeds. Moreover, the lack of knowledge on how to add value through proper storage, processing and marketing impedes agricultural growth. In opposition to these observations, IITA (2007) stated that promising techniques exist to address these problems. However, the extent to which these techniques are harnessed for agricultural development depends on the level of access to these techniques by cassava farmers. It is against this background that this study examined the extent to which cassava farmers have access to agricultural information in the study area

Purpose and objectives of the study 
The main purpose of the study was to examine the socio-economic characteristics of cassava farmers and their influence on their access to agricultural information in Delta State. Specifically, the study objectives were to:

1. examine cassava farmers' socio-economic characteristics in the study area;

2. identify cassava farmers' sources of agricultural information;

3. assess cassava farmers extent of access to agricultural information; and

4. examine the relationship between respondents' socio-economic characteristics and their access to agricultural information.

\section{Hypothesis of the study}

The following hypothesis was formulated for the study:

Ho: there is no significant relationship between cassava farmers' socio-economic characteristics and their access to agricultural information.

\section{Methodology}

The study was carried out in Delta State. The State is located in the South-South geopolitical zone of Nigeria. The State is made up of 25 Local Government Areas, constituted into three senatorial districts. The inhabitants are mostly farmers. Farmers who have cassava as their main crop constituted target population of the study. A multi-stage sampling technique was used in selecting the respondents for the study; a structured questionnaire was used to collect relevant information from the cassava farmers and analysed using frequency count, percentages while logit regression analysis was used to test the formulated hypothesis.

The Logit regression analysis is a form of regression used when the dependent variable is dichotomous or a dummy variable. The independent variable can be binary or continuous variables. It estimates the odd or likelihood of an event occurring. It is given as:

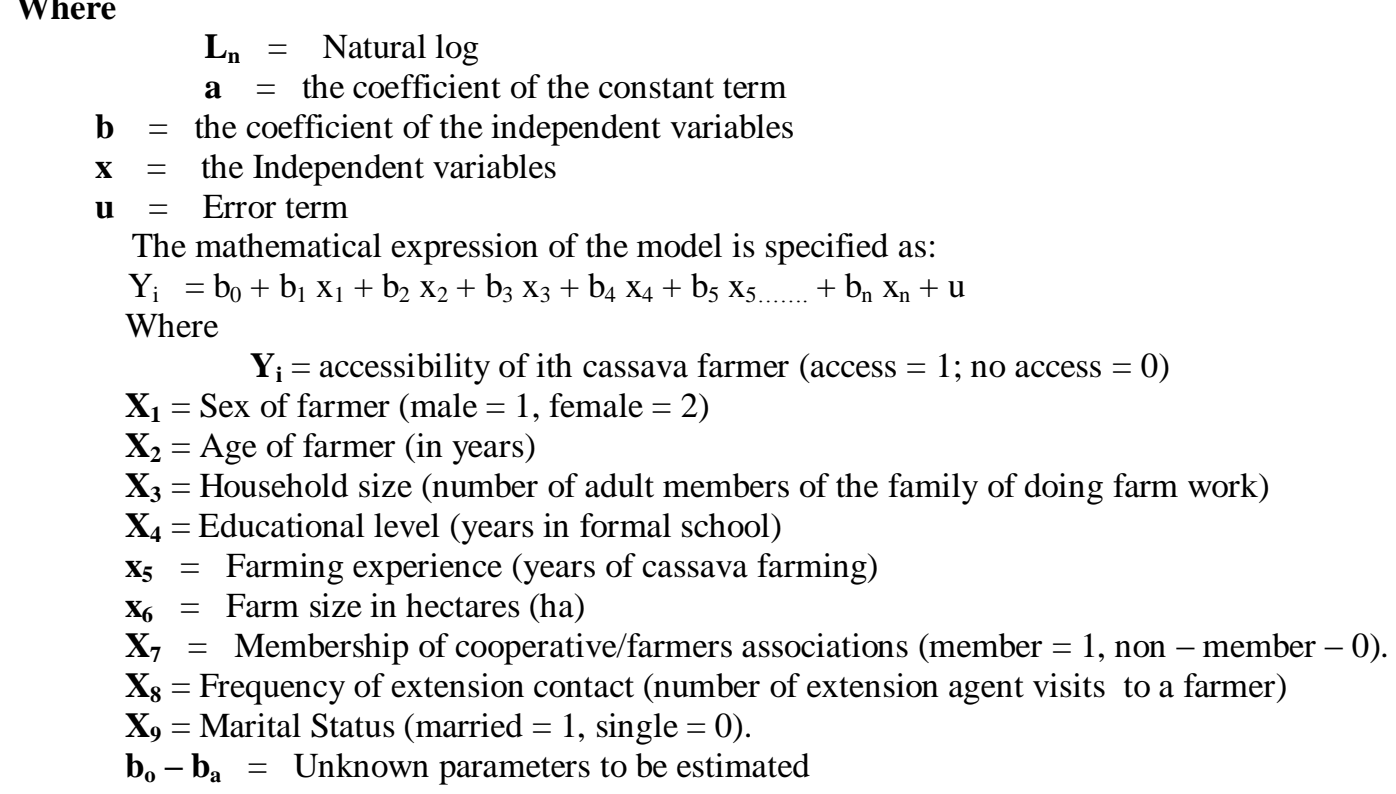

\section{Results and discussion}

Socio-economic characteristics of the respondents: Table 1 shows that the largest proportion of the respondents (35.6\%) was $41-50$ years, followed by the age group $21-30$ years $(22.6 \%)$. Their mean age was 44.8 years, indicating that most were economically active and of productive ages hence there is high prospect for agricultural information accessibility. Majority of the respondents (60.9\%) were males while females constitute $39.1 \%$. The result indicates that majority $(81.5 \%)$ were married, while few (13\%) were singles..

Data in Table 1 also revealed that majority of respondents $(43.2 \%)$ had a household size of $4-6$ members, followed by those with $7-9$ members $(28.8 \%)$, with the mean size being 6 . This means that the household size of the respondents was relatively large. This situation may invariably be an advantage to increase 
access to information and cheap farm labour in the household. About $82.2 \%$ of the respondents were literate while $17.1 \%$ can neither read nor write. A large proportion (41.8\%) of the literate class had tertiary education while $14.3 \%$ had no formal education. The high literacy level will aid the assessment of information (Torimiro, 1997).

Table 1, also shows that majority of the respondents $(30.8 \%)$ had more than 20 years of farming experience. The mean years of farming were 13 years. The result indicated that majority of the respondents (39.1\%) had a farm size of $0.1-0.5 \mathrm{ha}$, followed by $21.9 \%(0.6-1.0 \mathrm{ha})$. The mean farm size was 0.93 ha. According to Adesoye et al (2006), this farm size indicated that respondents were basically peasant farmers operating on small farm size. A large proportion of the respondents $(45.9 \%)$ belonged to cooperative society, $13.0 \%$ belonged to farmers association, and $5.5 \%$ belong to age grade while $35 \%$ do not belong to any social group. Above half of the respondents $45.2 \%$ had no contact at all with extension workers. Out of the other half, $23.3 \%$ had contact once a month with extension workers, $16.4 \%$ had contact twice a month while $15.1 \%$ of them had contact with extension worker once a week.

\section{Sources of agricultural information}

As shown in Table 2 the modal responses to friends and neighbours (46.6\%) get information always Most $(41.1 \%),(52.7 \%)$ and $(49.3 \%)$ of the respondents get information sometimes from Ministry of Agriculture and Natural Resources, Radio and television respectively. Friends and neighbours had a mean of 2.4, while Ministry of Agriculture and Natural Resources, Radio and Television had a mean

Table 1 Distribution of respondents according to socio-economic characteristics

\begin{tabular}{|c|c|c|c|c|c|}
\hline & Variables & Freq(n) & $\%$ & Mean & SD \\
\hline 1. & Sex & & & & \\
\hline a. & Male & 89 & 60.9 & & \\
\hline b. & Female & 57 & 39.1 & & \\
\hline 2. & Age & & & & \\
\hline a. & Below 20 years & 2 & 1.4 & & \\
\hline b. & $21-30$ years & 16 & 10.9 & & \\
\hline c. & $31-40$ years & 33 & 22.6 & 44.6 & 11.7 \\
\hline d. & $41-50$ years & 52 & 35.6 & & \\
\hline e. & $51-60$ years & 28 & 19.2 & & \\
\hline f. & 61 years and above & 15 & 10.3 & & \\
\hline 3. & Marital status & & & & \\
\hline a. & Single & 19 & 13.0 & & \\
\hline b. & Married & 119 & 81.5 & & \\
\hline c. & Divorce & 2 & 1.4 & & \\
\hline d. & Separated & 6 & 4.1 & & \\
\hline 4. & Household size (persons) & & & & \\
\hline a. & $1-3$ & 27 & 18.5 & 5.9 & 2.8 \\
\hline b. & $4-6$ & 63 & 43.2 & & \\
\hline c. & $7-9$ & 42 & 28.8 & & \\
\hline d. & $10-12$ & 10 & 6.8 & & \\
\hline e. & 13 and above & 4 & 2.7 & & \\
\hline 5. & Literacy level & & & & \\
\hline a. & Read only & 1 & 0.7 & & \\
\hline b. & Read and write & 120 & 82.2 & & \\
\hline c. & Neither write nor read. & 25 & 17.1 & & \\
\hline 6. & Level of education & & & & \\
\hline a. & No formal education & 21 & 14.3 & & \\
\hline b. & Primary school & 32 & 21.9 & & \\
\hline c. & Junior secondary school & 3 & 2.1 & & \\
\hline d. & Senior secondary school & 29 & 19.9 & & \\
\hline e. & Ond/nce & 30 & 20.5 & & \\
\hline f. & Hnd/b.sc & 29 & 19.9 & & \\
\hline g. & M.sc & 2 & 1.5 & & \\
\hline 7. & Religion & & & & \\
\hline a. & Christianity & 141 & 96.6 & & \\
\hline b. & Islam & 1 & 0.7 & & \\
\hline
\end{tabular}




\begin{tabular}{|l|l|l|l|l|l|}
\hline c. & Traditional religion & 4 & 2.7 & & \\
\hline 8. & Farming experience (years) & & & & \\
\hline a. & Less than 5 years & 25 & 17.1 & & \\
\hline b. & $5-10$ years & 34 & 23.3 & 13.6 & 7.4 \\
\hline c. & $11-20$ years & 42 & 28.8 & & \\
\hline d. & More than 20 years & 45 & 30.8 & & \\
\hline 9. & Farm size (ha) & & & & \\
\hline a. & $0.1-0.5$ ha & 57 & 39.1 & & \\
\hline b. & $0.6-1$. & 32 & 21.9 & 0.93 & 0.64 \\
\hline c. & $1.1-1.5$ ha & 31 & 21.2 & & \\
\hline d. & $1.6-2.0$ ha & 11 & 7.5 & & \\
\hline e. & 2.0 ha and above. & 15 & 10.5 & & \\
\hline 10. & Membership of social group & & & & \\
\hline a. & Farmers association & 19 & 13.0 & & \\
\hline b. & Cooperative society & 67 & 45.9 & & \\
\hline c. & Age grade & 8 & 5.5 & & \\
\hline d. & None & 52 & 35.6 & & \\
\hline e. & Others & - & - & & \\
\hline 11. & Contact with extension workers & & & & \\
\hline a. & Once a week & 22 & 15.1 & & \\
\hline b. & Once a month & 34 & 23.3 & & \\
\hline c. & Twice a month & 24 & 16.4 & & \\
\hline d. & Not at all & 66 & 45.2 & & \\
\hline
\end{tabular}

Source: Field survey data (2010)

of 2.00 each. Modal response to extension service (46.6\%) cooperative (42.5\%), Newspaper $(45.9 \%)$ and magazine (56.9\%) never get information from these sources. Equally, majority (60.3\%), (67.8\%), (79.5\%) and (74.0\%) never get information from Agro-chemical dealers, resource centres, internet and International Institute of Tropical Agriculture respectively. Data in the table further indicated that most respondents $81.5 \%, 78.0 \%$, 92.5\%, 93.8\% and $89.7 \%$ with a mean of 1.1 each, never get information from National Root Crop Research Institute, Shell Petroleum Development Company, National Agip Oil Company, Federal Institute of Industrial Research and Product Development Agency respectively. Furthermore, 90.4\% each had never get information from Faculty of Agriculture and University of Agriculture both had a mean of 1.1 each.

The result further highlighted the importance of Ministry of Agriculture and National Resources as a major source of information to cassava farmers. This confirmed the observation of Chris (2001) that the Ministry of Agriculture is regarded as a highly credible source of agricultural information and advice to farmers. Likewise the credibility of friends and neighbours as a major source of information to farmer is not in doubt. According to Chris (2001), farmer- to - farmer exchange of agricultural information is the best source of information to farmers. However, the implication of this finding is that respondents may not have access to technical information because information received from friends and neighbours may be less reliable on technical issues. Radio and television were also revealed as popular source of information. This is in conformity with several communication studies which have shown that the mass media source of communication remains popular both in developed and third world countries (ICS - Nigeria, 2007). Radio and where available television, are the best source of information (FAO, 2000). However, Adekunle, el at (2002) observed that farmers in Abia State preferred radio to television. This implies that the ownership of a functional radio and television will enhance agricultural information accessibility.

\section{Awareness of agricultural information}

Respondents' awareness of cassava related information is presented in Table 3. The result revealed that $84.2 \%$ were aware of improved cassava varieties, $81.5 \%$ were aware of fertilizer type, $79.5 \%$ were aware of fertilizer application and disease control methods. In respect to processing chips and pellets $36.3 \%$ were aware while $57.5 \%$ were aware of information on processing starch and glue. It was also observed that $50.7 \%$ were aware of processing animal feed, while $63.0 \%$ were aware of processing equipments. Data in the table further indicated that $67.8 \%$ were aware of storage methods, half of the respondents were aware of packaging information while $80.1 \%$ were found to be aware of available market for produce. The table also revealed that $67.1 \%, 76.7 \%$ and $52.1 \%$ were aware of input price, produce price and credit facility respectively while $60.9 \%$ and $63.7 \%$ were not aware of information on disease control method and processing chips and pellets. 
Empirical Analysis of Cassava Farmers Socio - Economic Characteristics and Their Access to

Table 2: Distribution of respondents according to sources of agricultural information

\begin{tabular}{|c|c|c|c|c|c|c|c|c|c|}
\hline & \multirow[t]{2}{*}{ Sources of information } & \multicolumn{2}{|c|}{ Always } & \multicolumn{2}{|c|}{ Sometimes } & \multicolumn{2}{|c|}{ Never } & \multirow[b]{2}{*}{$\bar{X}$} & \multirow[b]{2}{*}{ SD } \\
\hline & & Freq & $\%$ & Freq & $\%$ & Freq & $\%$ & & \\
\hline 1. & Friends and Neigbours & 68 & 46.6 & 61 & 41.8 & 17 & 11.6 & 2.4 & 0.78 \\
\hline 2. & $\begin{array}{l}\text { Ministry of Agric and National and } \\
\text { Resource }\end{array}$ & 40 & 27.4 & 60 & 41.1 & 46 & 31.5 & 2.0 & 0.70 \\
\hline 3. & Radio & 35 & 24.0 & 77 & 52.7 & 34 & 23.3 & 2.0 & 0.76 \\
\hline 4. & Television & 33 & 22.6 & 72 & 49.3 & 41 & 28.1 & 2.0 & 0.77 \\
\hline 5. & Extension services & 32 & 21.9 & 46 & 31.5 & 68 & 46.6 & 1.2 & 0.71 \\
\hline 6. & Cooperative & 25 & 17.1 & 59 & 40.4 & 62 & 42.5 & 1.7 & 0.69 \\
\hline 7. & Newspaper & 20 & 13.7 & 59 & 40.4 & 67 & 45.9 & 1.7 & 0.73 \\
\hline 8. & Agro-chemical dealers & 11 & 7.5 & 47 & 32.2 & 88 & 60.3 & 1.5 & 0.75 \\
\hline 9. & Magazine & 13 & 8.9 & 50 & 34.2 & 83 & 56.9 & 1.5 & 0.76 \\
\hline 10. & Resource Centres & 3 & 2.1 & 44 & 30.1 & 99 & 67.8 & 1.3 & 0.74 \\
\hline 11. & Internet & 5 & 3.4 & 25 & 17.1 & 116 & 79.5 & 1.3 & 0.77 \\
\hline 12. & $\begin{array}{l}\text { Int'l Institute of Tropical } \\
\text { Agriculture (IITA) }\end{array}$ & 5 & 3.4 & 33 & 22.6 & 108 & 74.0 & 1.2 & 0.70 \\
\hline 13. & $\begin{array}{l}\text { National Root Crop Research } \\
\text { Institute }\end{array}$ & 2 & 1.4 & 25 & 17.1 & 119 & 81.5 & 1.2 & 0.69 \\
\hline 14. & $\begin{array}{l}\text { Shell Petroleum Development } \\
\text { Company }\end{array}$ & 3 & 2.1 & 29 & 19.9 & 114 & 78.0 & 1.2 & 0.66 \\
\hline 15. & National Agip Oil Company & 1 & 0.7 & 10 & 6.8 & 135 & 92.5 & 1.1 & 0.70 \\
\hline 16. & $\begin{array}{l}\text { Federal Institute of Industrial } \\
\text { Research }\end{array}$ & 2 & 1.4 & 7 & 4.8 & 137 & 93.8 & 1.1 & 0.69 \\
\hline 17. & $\begin{array}{l}\text { Product Development Agency } \\
\text { (PDA) }\end{array}$ & 5 & 3.4 & 10 & 6.9 & 131 & 89.7 & 1.1 & 0.68 \\
\hline 18. & Faculty of Agriculture & 7 & 4.8 & 17 & 11.6 & 122 & 90.4 & 1.1 & 0.71 \\
\hline 19. & University of Agriculture & 2 & 1.4 & 12 & 8.2 & 132 & 90.4 & 1.1 & 0.66 \\
\hline
\end{tabular}

Source: Field survey data $(\mathbf{2 0 1 0}) \quad$ Mean $=\mathbf{2 . 0 0}$

Awareness proceeds access and utilization as you cannot seek for what you do not know that exist. However, awareness can be generally said to be high as respondents were not aware of only two agricultural information types (Disease control method and Processing chip/ pellets).

\section{Cassava farmers access to agricultural information}

Table 4 looked at respondents' access to agricultural information. As seen in the table, majority $(45.5 \%)$ indicated that they had access to information on available market for produce always, $48.8 \%$ and $37 . \%$ had access to information on produce price, and input price always for use respectively.

Table 3: Distribution of respondents according to awareness of agricultural information

\begin{tabular}{|l|l|c|c|c|c|}
\hline \multirow{2}{*}{ Information type } & \multicolumn{2}{c|}{ Aware } & \multicolumn{2}{c|}{ Not aware } \\
\cline { 3 - 5 } & Freq(n) & $\mathbf{\%}$ & Freq(n) & $\%$ \\
\hline 1. & Improved cassava varieties & 123 & 84.2 & 23 & 15.8 \\
\hline 2. & Fertilizer type & 119 & 81.5 & 27 & 18.5 \\
\hline 3. & Fertilizer application & 116 & 79.5 & 30 & 20.5 \\
\hline 4. & Pest control method & 91 & 62.3 & 55 & 37.7 \\
\hline 5. & Disease control method & 57 & 39.1 & 89 & 60.9 \\
\hline 6. & Processing chip/ pellets & 53 & 36.3 & 93 & 63.7 \\
\hline 7. & Processing starch \& glue & 84 & 57.5 & 62 & 42.5 \\
\hline 8. & Processing equipments & 92 & 63.0 & 54 & 37.0 \\
\hline 9 & Storage methods & 99 & 67.8 & 47 & 32.2 \\
\hline 10. & Packaging & 73 & 50.0 & 73 & 50.0 \\
\hline 11. & Available market produce & 117 & 80.1 & 29 & 19.9 \\
\hline 13. & Input price & 98 & 67.1 & 48 & 32.9 \\
\hline 14. & Produce price & 112 & 76.7 & 34 & 23.3 \\
\hline 15. & Credit facility & 76 & 52.1 & 70 & 47.9 \\
\hline
\end{tabular}

\section{Source: Field survey data (2010)}

The mean values suggest that the respondents had access to information on produce price $($ mean $=2.3)$ and available market for produce (2.3) improved cassava varieties (2.1), fertilizer type (2.1) and fertilizer application (2.1). The respondents had no access to information on the following: processing equipment (mean = 1.8), processing animal feed (1.7) and pest control method (1.7). The results also indicated that respondents had 
no access to information on disease control method (mean $=1.6)$, processing starch and glue $(1.6)$, credit facility (1.6) and packaging (1.6), processing chips and pellets (1.4). This result indicated that cassava farmers had access to six agricultural information types. This implies that respondents know where to get this information and can get the information for use whenever the need arises. Access can be generally described to be low because respondents had access to only six information types as against fifteen information types.

Table 4: Distribution of respondents by access to cassava related information

\begin{tabular}{|l|l|l|l|l|l|l|l|l|l|}
\hline & \multirow{2}{*}{ Access to information } & \multicolumn{2}{|c|}{ Always } & \multicolumn{2}{l|}{ Sometime } & Never & & \\
\cline { 3 - 11 } & & Freq & $\mathbf{\%}$ & Freq & $\mathbf{\%}$ & Freq & $\mathbf{\%}$ & $\mathbf{X}$ & Sd \\
\hline 1. & Available market for & 66 & 45.2 & 54 & 37.0 & 26 & 17.8 & 2.3 & 1.20 \\
\hline 2. & Produce & 64 & 48.8 & 48 & 32.9 & 34 & 23.3 & 2.3 & 1.21 \\
\hline 3. & Input price & 54 & 37.0 & 50 & 34.2 & 42 & 28.8 & 2.1 & 1.04 \\
\hline 4. & Improved cassava varieties & 46 & 31.5 & 74 & 50.7 & 26 & 17.8 & 2.1 & 0.99 \\
\hline 5. & Fertilizer type & 50 & 34.2 & 263 & 43.2 & 33 & 22.6 & 2.1 & 1.04 \\
\hline 6. & Fertilizer application & 48 & 32.9 & 68 & 46.6 & 30 & 20.5 & 2.1 & 1.00 \\
\hline 7. & Storage method & 37 & 25.4 & 58 & 39.7 & 51 & 34.9 & 1.9 & 0.91 \\
\hline 8. & Processing equipment & 32 & 21.9 & 55 & 37.7 & 59 & 40.4 & 1.8 & 0.91 \\
\hline 9. & Processing animal feed & 25 & 17.1 & 51 & 34.9 & 70 & 48.0 & 1.7 & 0.90 \\
\hline 10. & Pest control method & 31 & 21.2 & 44 & 30.2 & 71 & 48.6 & 1.7 & 0.90 \\
\hline 11. & Disease control method & 26 & 17.8 & 43 & 29.5 & 77 & 52.7 & 1.6 & 0.89 \\
\hline 12. & Processing starch \& glue & 24 & 16.4 & 47 & 32.2 & 75 & 51.4 & 1.6 & 0.88 \\
\hline 13. & Credit facility & 23 & 15.8 & 47 & 32.2 & 76 & 52.0 & 1.6 & 0.88 \\
\hline 14. & Packaging & 24 & 16.4 & 43 & 29.5 & 79 & 51.1 & 1.6 & 0.88 \\
\hline 15. & Processing chips \& pellets & 18 & 12.3 & 29 & 19.9 & 99 & 67.8 & 1.4 & 0.71 \\
\hline
\end{tabular}

Source: Field survey data (2010) Mean $\geq 2.00$.

\section{Accessibility to agricultural information}

Result of the classification analysis on accessibility to agricultural information shows that $65.7 \%$ of the respondents had low access to agricultural information because they had an aggregate mean score equal or less than 30 while $34.3 \%$ had high access because their aggregate mean score on all information items were greater than 30. The low access could be due to the low level of education of respondents, none membership of association by most respondents and inadequacy of extension service in the study area.

Table 5: Accessibility to agricultural information

\begin{tabular}{|l|c|c|}
\hline Access status & Frequency & \% \\
\hline Low & 96 & 65.7 \\
\hline High & 50 & 34.3 \\
\hline Total & $\mathbf{1 4 6}$ & $\mathbf{1 0 0}$ \\
\hline
\end{tabular}

Source: Field survey data (2010)

\section{Hypotheses testing}

Relationship between socio-economic characteristics and access to agricultural information: Table 5 shows the logistic regression between respondents' socio-economic characteristics and their access to agricultural information. The Omnibus test is significant at $5 \%\left(\xi^{2)}=18.06, \mathrm{P}<0.05\right)$ and implies that the regression model containing the various independent variables is better in explaining farmers access to agricultural information than the model without the variables. The Hosmer and Lemeshow test is not significant at the $5 \%$ level $\left(\xi^{2)}=5.92, \mathrm{P}>0.05\right)$, which implies that the data used in the model is not significantly different from real life scene. In other words the result or data used is a good representation of the real life situation. The $\%$ correctness of the classification of respondents into high and low access is about $70 \%$. This means the model correctly predict the respondents' degree of access to agricultural information by $70 \%$.

The coefficient of determination $\left(\mathrm{R}^{2}\right)$ is 0.561 which means the variables in the model account for $56.1 \%$ variation in respondents' likelihood of having high access to agricultural information. Out of the nine explanatory variables in the model, only three were significant as their calculated t-statistics were greater than the tabulated $\mathrm{t}$-statistics at $5 \%$ level. These were education $(\mathrm{t}=2.522)$, association membership $(\mathrm{t}=2.27)$ and extension contact $(t=2.080)$. Education had positive coefficient $(b=0.29)$ or influence on respondents likelihood of having high access to agricultural information. The odd ratio is 1.34 which means that those with 
higher education are 1.3 times or $30 \%$ more likely to have higher access to agricultural information than those with lower education. The ability to read and write is a factor that will positively influence access to information. Being literate, it is expected that respondents will be more dispose to information as it has been observed by researchers that literacy aid access to information and adoption (Onemolease, 2004; Okunlola, 2005).

Association membership also had positive $(b=0.323)$ influence on respondents likelihood of having high access to agricultural information. It should be noted that it is the membership of agricultural based associations such as cooperatives and farmers association etc that have positive influence in accessibility. Cooperatives like farmers union are reliable sources of information on improve practices and new technology to farmers (Akinloye, et al., 2005). Ekong (2003) noted that cooperative is a major promoter of members' education. The table also revealed that extension contact have positive $(b=0.364)$ influence on respondent likelihood of having high access to agricultural information. The odd ratio is 1.439 which implies that those that had contact with extension workers are 1.4 times or $40 \%$ more likely to have high access to agricultural information than those that do not have contact with extension services. FAO (2000) opined that extension service is the best means of information to most farmers. Extension services are essentially communicative and bear great potentials in promoting access to information and productively of farmers (Adebayo et al, 2003).

Table 6: logistic regression result for socio-economic factors affecting respondents access to agricultural information

\begin{tabular}{|l|l|l|l|l|}
\hline Variables & $\mathrm{B}$ & $\mathrm{T}$ & $\mathrm{p}$ & Odd ratio \\
\hline Sex & 0.671 & 1.605 & 1.108 & 1.956 \\
\hline Age & -0.318 & -1.507 & 0.131 & 0.728 \\
\hline Household size & -0.107 & -0.505 & 0.613 & 0.899 \\
\hline Education & 0.29 & 2.522 & 0.022 & 1.336 \\
\hline Farming experience & 0.07 & 0.327 & 0.743 & 1.073 \\
\hline Farm size & -0.192 & -1.193 & 0.233 & 0.825 \\
\hline Association membership & 0.323 & 2.275 & 0.0392 & 1.381 \\
\hline Extension contact & 0.364 & 2.080 & 0.041 & 1.439 \\
\hline Marital status & 1.109 & 1.789 & 0.074 & 3.031 \\
\hline Constant & -1.15 & -1.04 & 0.298 & 0.317 \\
\hline
\end{tabular}

Omnibus Test $\left(\xi^{2)}=18.06(\mathrm{p}<0.05) ;\right.$ Hosmer and Lemeshow Test $\left(\xi^{2}\right)=5.92(\mathrm{p}>0.05) ; \mathrm{R}^{2}=0.561 ; \%$ correctness $=69.9$

\section{Conclusion}

The findings from this study show that accessibility of cassava farmers to agricultural information in Delta State is generally low (65.7\%). The study identified four major sources of information to respondents namely Ministry of Agriculture and Natural Resources, friends and neighbours, radio and television. The study revealed that respondents had access to only information on improved cassava varieties, fertilizer type and fertilizer application, available market for produce, input price and produce price.

The test of relationship between socio-economic characteristics and accessibility showed only education; association membership and extension contact had significantly influence on respondents' access to cassava related information.

Based on the findings of the study, the following suggestions are made:

1. ADP should be empowered through better funding and staff training to bridge the gap between researchers and farmers.

2. Information sources to cassava farmers should be identified and used to communicate agricultural information to farmers by research institute.

3. Farmers should be encouraged to form association such as agricultural cooperatives, farmers association which will be good means of disseminating information to farmers.

4. Adult education should be encouraged among cassava farmers especially in rural areas.

\section{References}

[1] Adebayo, K. Anyanwu, A.C and Dsiyale, A.O. (2003): Perception of environmental issues by cassava processors in Ogun State, Nigeria - Implications for environmental extension education: Journal of Extension systems 19:103 - 112.

[2] Adekunle, A.A., Ononiwu, G., Ogunyika, O., Chugbo, C. (2002): Agricultural information dissemination in Abia State: An audience survey. IITA Report, Ibadan Nigeria.

[3] Adesoje, S.A., Farinde, A.J. and Ajayi, A.O. (2006): Determinants of training needs of Fadama farmers in Osun State, Nigeria and implication for extension workers. Journal for applied Sciences 6(15): 3082-3088.

[4] Akinloye, J.F., and Banji, O.A. (2005): Role of Community Based Organizations (CBOs), Commodity Associations (CAs) and NonGovernmental Activities in Nigeria. Journal of Agricultural Extension society of Nigeria (AESON).PP $208-218$. 
[5] Banmeke, T.O.A and Olowu, T.A. (2005): Accessibility of women farmers to agricultural information in South Western Nigeria. South African Journal of Agricultural Extension 34 (2): 237 - 246.

[6] Chris, G., (2001): Agricultural knowledge and information system in Hagaz, Eritres. International and Rural Development department. The University of Reading, United Kingdom http:llwww.fao.org/sd $/ 2001 / \mathrm{kn1001a-} \quad$ en.htm. assessed $12^{\text {th }}$ December, 2008 .

[7] Ekong, E.E. (2003): An Introduction to Rural Sociology. Second edition, Dove educational publishers, 80 Wellington Bassey, Uyo. Nigeria.

[8] Food and Agricultural Organisation (2000): Marketing Extension

Guide 2: Understanding and using market information. FAO of the United Nations, Rome.

[9] ICS-Nigeria (2007): Information and Communication Support for Agricultural Growth in Nigeria http:llwww.ics-nigeria.org.

[10] International Institute for Tropical Agriculture (2004): Nigeria's Cassava Industry: Statistical Handbook, Ibadan, Nigeria.

[11] Okunlola, J.O. (2005): Factors affecting Fadama Farming System in South Western Nigeria. Proceeding of Annual Conference on Development in Agricultural and Biological Sciences, $27^{\text {th }}$ April 2005, Federal University of Technology, Akure, Nigeria, PP 125180 .

[12] Onemolease, E.A. (2004): Impact of Agricultural Development Programme (ADP) activities on alleviation of rural poverty in Edo State, Nigeria. PhD thesis, Department of Agricultural Economics and Extension, University of Benin, Benin City, Nigeria.

[13] Ozowa, V.N. (2004): Information Needs of Small Scale Farmers in Africa. The Nigeria Example. Quarterly Bulletin of the International Association of Agricultural Information Specialist, IAALD/CABI, vol. 40 No 1 PP $22-30$.

[14] Torimiro, D.O. (1997): The relationship between socio-economic characteristics of farmers and adoption of improved agricultural technology in Ogun State, Nigeria. The Rural Sociologist, vol. 2 PP $22-28$. 